\section{Cemongersume}

Cuestiones Constitucionales

ISSN: 1405-9193

rmdc@servidor.unam.mx

Universidad Nacional Autónoma de México

México

Martínez Torrón, Javier

Derecho de asociación y confesiones religiosa sen la constitución de 1931

Cuestiones Constitucionales, núm. 3, julio-diciembre, 2000, pp. 91-120

Universidad Nacional Autónoma de México

Distrito Federal, México

Disponible en: http://www.redalyc.org/articulo.oa?id=88500305

- Cómo citar el artículo

- Número completo

- Más información del artículo

Página de la revista en redalyc.org

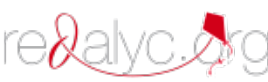

Sistema de Información Científica

Red de Revistas Científicas de América Latina, el Caribe, España y Portugal

Proyecto académico sin fines de lucro, desarrollado bajo la iniciativa de acceso abierto 


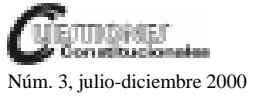

\title{
DERECHO DE ASOCIACIÓN Y CONFESIONES RELIGIOSAS EN LA CONSTITUCIÓN DE 1931*
}

\author{
Javier MARTÍNEZ-TORRÓN
}

RESUMEN: El autor hace un análisis objetivo de la situación social, política y jurídica de España en la Segunda República, respecto de la relación entre el Estado, el derecho de asociación y las confesiones religiosas. Afirma que el fracaso de la Segunda República respecto de la cuestión religiosa fue resultado de la incapacidad de diálogo político de los participantes que tomaron posiciones inflexibles de enfrentamiento entre los católicos y los socialistas. La Constitución y la Legislación Republicana han pasado a la historia como un ejemplo de falta de realismo y de intolerancia religiosa. Concluye el autor que la delimitación precisa de lo que corresponde a la sociedad civil y a la sociedad religiosa, y sus consecuencias respecto a la estructura política del Estado, fue y es materia abierta de discusión.

\begin{abstract}
The author makes an objective analysis of the social, political and juridical situation in Spain during the Second Republic, with respect to the relationship between the State, the rights of association and religious confessions. He affirms that the breakdown of the Second Republic with regard to the religious question was the result of the participants' incapacity for political dialogue, and the adoption between Catholics and Socialists of inflexibly opposed positions. The Republican Constitution and Legislation have passed to History as an example of the lack of realism and of religious intolerance. The author concludes that a specific delimitation of what corresponds to civil society and what to religious society, and the consequences of same with respect to the political structure of the State, was and is an open matter for discussion.
\end{abstract}

\section{INTRODUCCIÓN}

Debo advertir desde el principio que, al abordar el tema que en su día me propusieron, fue imposible evitar reiteraciones con algunos otros de los temas presentes en estas jornadas sobre Estado y religión en homenaje

* Este artículo recoge sustancialmente el texto de una ponencia presentada en las jornadas “Estado y religión. Proceso de secularización y laicidad. Homenaje a D. Fernando de los Ríos", celebradas en la Universidad Carlos III (Madrid) del 9 al 11 de noviembre de 1999. Deseo agradecer a los profesores Rafael Navarro-Valls y José María Vázquez García-Peñuela su amable lectura del manuscrito original de estas páginas, y las sugerencias que han contribuido a mejorar su contenido. 
a Fernando de los Ríos. Efectivamente, la relación entre el derecho de asociación y las confesiones religiosas en la Constitución republicana de 1931 nos conduce necesariamente a la regulación de las órdenes y las congregaciones religiosas. La cual, a su vez, constituye el tema capital de lo que se llamó entonces la "cuestión religiosa", que enfrentaba entre sí a las posiciones en pro de la secularización del Estado y en favor de los derechos históricos de la Iglesia católica, respectivamente. Por otro lado, el objetivo principal de las posiciones secularizadoras era limitar la influencia de la Iglesia, uno de cuyos instrumentos principales eran los centros de enseñanza dirigidos por congregaciones religiosas.

Laicidad, órdenes religiosas y enseñanza reclaman, por tanto, un tratamiento inseparable, pues son los temas centrales que convergen en el estudio de la cuestión religiosa en la Segunda República. Y debo indicar también que no es temática fácil de analizar, por distintas razones.

Por una parte está lo que podríamos llamar la presión intelectual que ejerce el tratamiento de esta temática extramuros de la Universidad. En efecto, no resulta frecuente que, fuera del ámbito universitario, los temas relativos a la Segunda República española sean estudiados, y menos aún expuestos, con la suficiente ecuanimidad e imparcialidad de criterio. La razón no es sólo nuestra proximidad temporal a los acontecimientos, que ya no es tanta. Sucede, además, que, en la reciente historia política de España, se han revitalizado a veces algunos de los planteamientos de entonces, con afán, no tanto de sacar a la luz nuevas verdades, cuanto de difundir una interpretación sesgada de ese periodo - de triste final- de nuestra historia contemporánea. En otras palabras, no faltan quienes, a casi setenta años de distancia, y desde perspectivas opuestas, pretenden todavía "resucitar los fantasmas del pasado" con una versión parcial - y por tanto inexacta - de lo sucedido en esos cinco agitados años que transcurren desde la proclamación de la Segunda República hasta que la guerra civil fuera iniciada por el alzamiento militar de julio de 1936.

Naturalmente, en el contexto en que ahora nos encontramos, se persigue una finalidad bien diferente. Se pretende un análisis lo más objetivo posible de cómo la regulación de las confesiones religiosas fue abordada por la Constitución de 1931, así como de las consecuencias jurídicas, políticas y sociales que produjo ese tratamiento constitucional. 
Pienso que todos los presentes estaremos de acuerdo en que, al revisar un tema histórico como el que aquí se me propone, lo importante es "poner las cosas en su sitio". Lo cual nos lleva a la pregunta crucial: cuál es el sitio de cada cosa. Pero esa pregunta no es fácil de contestar sin que las personales posiciones ideológicas maticen la intención de objetividad que ha de estar presente en todo análisis intelectual riguroso, como debe serlo el que se realiza en el entorno universitario. Sobre todo porque la objetividad resulta especialmente problemática en este caso, pues la libertad religiosa es uno de los derechos humanos más sensibles a sufrir, incluso en su estudio académico, el embate de las distintas opciones sobre el diseño fundamental de la organización política del Estado. Los temas relacionados con la libertad religiosa son difíciles de estudiar sin que tenga lugar una influencia - a veces subconsciente- de las propias ideas acerca de "cómo deberían ser las cosas" en las relaciones Iglesia-Estado, o, para ser más preciso, en las relaciones entre Estado y hecho religioso.

De ahí que la prudencia aconseje, antes de adentrarse en un tema como éste, adoptar una doble precaución. Por una parte, explicitar en su caso, cuando sea necesario, el peso que las opciones ideológicas personales tienen de hecho en el análisis que se realiza. ${ }^{1}$ Por otra parte, y sobre todo, evitar una interpretación maniquea de la historia, hacer una historia de inocentes y culpables, de "buenos" y "malos".

Las características del tema reclaman sin duda una revisión crítica de ese periodo de la historia española, que nos permita aprender de la experiencia pasada para no incurrir en los mismos errores. Revisión significa detectar los hechos con objetividad. Crítica implica valorarlos, es decir, señalar lo que se entiende como errores y como aciertos. Pero esa revisión crítica debe efectuarse sin demonizar a unos protagonistas y beatificar a otros; no sólo por elementales consideraciones deontológicas, sino también por lo que podríamos llamar "cautela metodológica", pues la historia rara vez arroja una nítida distinción entre lo blanco y lo negro: más bien presenta una variada gama de grises.

En fin, no quiero prolongar más estas observaciones introductorias. Sólo deseo aclarar que mi exposición deberá ser necesariamente breve,

1 Me remito aquí a mis observaciones al respecto en Martínez-Torrón, J., Religión, derecho y sociedad. Antiguos y nuevos planteamientos en el derecho eclesiástico del Estado, Granada, 1999, pp. 19-20. 
por razón del tiempo disponible. Y que en ella no pretendo aportar nada sustancialmente nuevo por lo que se refiere a los hechos: ya hay muchas páginas escritas y bien documentadas al respecto. ${ }^{2}$ Mi intención será recordar algunas cosas - a veces recordar es importante - y analizarlas desde la perspectiva que confiere la posterior experiencia jurídica y política.

\section{LA SEGUNDA REPÚBLICA Y LA CUESTIÓN RELIGIOSA}

Una de las cosas - bien sabidas - que conviene recordar desde el principio es que la cuestión religiosa fue una cuestión clave en la Segunda República, y por tanto una de las razones que explican sus turbulentas vicisitudes y su terminación violenta. ${ }^{3}$ Probablemente no es algo positivo que así fuera, sobre todo dado el devenir de los acontecimientos, pero es un hecho indiscutible.

No fue positivo, me parece, que la religión se convirtiera en una cuestión central de los agrios enfrentamientos políticos y sociales que se produjeron en España entre 1931 y 1936 . Y no fue positivo, tampoco, el modo en que la cuestión fue afrontada por casi todos los protagonistas

2 Por las características de esta intervención, y por la abundancia de literatura — de diversa calidad y orientación - sobre la Segunda República española, he preferido limitar las citas, por lo general, a los escritos que se han ocupado más directamente de la cuestión religiosa. Entre ellos, y sin perjuicio de los trabajos que se citarán más adelante, son especialmente útiles las obras de Cárcel Ortí, V., La persecución religiosa en España durante la Segunda República (1931-1939), Madrid, 1990; Meer, F. de, La cuestión religiosa en las Cortes Constituyentes de la II República española, Pamplona, 1875; y Redondo, G., Historia de la Iglesia en España, 1931-1939, vol. 1: La Segunda República (1931-1936), Madrid, 1993. Entre las obras históricas generales sobre la Segunda República, véase J. M. García Escudero, Historia política de las dos Españas, 2a. ed., Madrid, 1976; Jackson, G., La República española y la guerra civil, Madrid, 1978; Payne, S. G., La revolución y la guerra civil española, Barcelona, 1977; Tuñón de Lara, M., La II República, Madrid, 1976.

3 De Manuel Azaña, uno de los personajes más influyentes en la política republicana, que fue sucesivamente ministro de la Guerra, presidente del Gobierno y presidente de la República, son las siguientes palabras, escritas poco después de la guerra civil y poco antes de su muerte: "Cada vez que repaso los anales del Parlamento constituyente y quiero discernir dónde se jugó el porvenir de la política republicana y dónde se atravesó la cuestión capital que ha servido para torcer el rumbo de la política, mi pensamiento y mi memoria van inexorablemente a la Ley de Congregaciones Religiosas, al artículo 26o. de la Constitución, a la política laica, a la neutralidad de la escuela..." (citado por Martí Gilabert, F., Política religiosa de la Segunda República española, Pamplona, 1998, p. 88). 
de la vida política española, bien por voluntad propia, bien por no tener alternativas viables.

En todo caso, no es aventurado afirmar que gran parte — quizá la mayor parte- del fracaso de la Segunda República se debió a la insatisfactoria solución que se dio a la cuestión religiosa. Sin duda hubo también otros problemas acuciantes y mal resueltos, como la política social —en especial la reforma agraria—, o la autonomía de las regiones. Pero la cuestión religiosa fue la que polarizó un más alto porcentaje de esfuerzos, en direcciones divergentes, y de contiendas.

Es presumible que la principal causa de ese protagonismo de lo religioso consistiera en que, para muchos personajes de la vida política, la Segunda República estaba indisolublemente ligada a una renovación de la tradicional actitud del Estado español en relación con el factor religioso. Se veía en la República una ocasión insustituible para cambiar el rumbo de la política religiosa en España, hasta entonces anclada en una secular confesionalidad católica, lo cual se había traducido en varias formas de estrecha colaboración entre la monarquía y la Iglesia - no exenta de momentos de fricción-, que incluían una decidida tutela estatal de la fe católica frente a otras alternativas religiosas o ideológicas, y una cierta intervención estatal en asuntos eclesiásticos (especialmente a través del derecho de presentación consignado en el Concordato de 1851). Ese modo de entender el desarrollo institucional de la Segunda República, a su vez, recibió diversas interpretaciones.

En algunos casos, el cambio que se pretendía era una verdadera metamorfosis. Se pretendía, contra todo realismo, suplantar la religiosidad católica arraigada en gran parte del pueblo español por un agnosticismo o por un ateísmo - unas veces menos ilustrados que otras- que habían de ser impulsados, o incluso impuestos, desde el poder. Era ésta una actitud vindicativa que buscaba, sin paliativos, y como un fin en sí mismo, acabar con la influencia social de la Iglesia católica en España. Con frecuencia, tal actitud era alimentada por la suposición de que había una estrecha asociación entre las fuerzas monárquicas y el establishment eclesiástico: cortadas las alas de éste, se aseguraba que la monarquía no pudiera resurgir de entre sus cenizas. La consecuencia natural de esa visión — simplificada e inexacta — de la realidad era propugnar una hostilidad abierta e intransigente contra todo lo que supusiera presencia social de instituciones eclesiásticas. 
En otros casos, las actitudes proclives a modificar el régimen de las relaciones Iglesia-Estado eran más moderadas, y provenían, no sólo de ciertos sectores de inspiración intelectual agnóstica, sino también de personas de declarada procedencia católica. Su intención partía de una base mucho más realista, que no ignoraba el peso social de la Iglesia católica, ni perseguía un enfrentamiento violento con ella. Se trataba, más bien, de "liberar al Estado del yugo eclesiástico", de modernizar nuestra estructura política, de contrarrestar la influencia eclesiástica que — para muchas personas - tantas veces había constituido un elemento de intolerancia y un freno al progreso de la ciencia y de las ideas en España. ${ }^{4}$ Esta actitud se materializaba en proponer una separación entre Estado e Iglesia bastante similar, en sus perfiles jurídicos, al modelo francés; algo que hoy resultaría aceptable en términos generales, pero que entonces — conviene no olvidarlo - era anatemizado por la jerarquía eclesiástica.

Frente a esas posiciones renovadoras, la jerarquía eclesiástica, así como la clase política católica más influida por la jerarquía, tenía más bien la disposición de mantener en esencia, y en lo posible, el statu quo de que gozaba la Iglesia católica: es decir, preservar los "derechos de la Iglesia". La idea de fondo era que su privilegiada relación de cooperación con el Estado no se viera perjudicada por el paso del régimen monárquico al republicano. $\mathrm{Y}$ es que, efectivamente, y no obstante la natural reserva que podía sugerir el clima político imperante, ni la Santa Sede ni el episcopado español expresaron oposición a la República en un primer momento. ${ }^{5} \mathrm{Al}$ contrario, con algunas excepciones aisladas, la jerarquía eclesiástica recomendó prudentemente el respeto al orden constituido y a la nueva legalidad republicana.

Las fricciones con el poder civil surgieron más tarde, a raíz de la relativa pasividad de los poderes públicos en muchos lugares ante

4 Ésta era la línea adoptada por buena parte de los intelectuales españoles de prestigio, como Ortega y Gasset, Marañón, Sánchez Román, Sánchez Albornoz, Ossorio Gallardo y Pérez Serrano, y por algunos miembros del gobierno provisional de la Segunda República, como Alejandro Lerroux y Fernando de los Ríos. Entre los católicos, el caso más significado fue el de Alcalá Zamora, católico liberal, que presidió el gobierno provisional y que, tras su dimisión — provocada precisamente por la solución dada por las Cortes constituyentes a la cuestión religiosa-, fue el primer presidente constitucional de la Segunda República.

5 Véase Cárcel Ortí, V., "La Iglesia durante la II República y la Guerra Civil (1931-1939)", Historia de la Iglesia en España (dirigida por R. García-Villoslada), vol. 5, pp. 343 y ss.; Meer, F. de, La cuestión religiosa..., cit., pp. 28 y ss. 
ciertos desórdenes sociales dirigidos contra instituciones eclesiásticas, ${ }^{6}$ y sobre todo a raíz de los debates de las Cortes constituyentes y de la posterior aprobación definitiva del texto constitucional de 1931. Aun así, y a pesar de que muy pronto se vio que las cosas no podrían continuar como antes, la jerarquía eclesiástica no respondió de forma beligerante.

Es cierto que hubo un sector minoritario de la jerarquía que adoptó una línea "dura", en paralelo a la de los extremistas anticatólicos. A la vista de los acontecimientos, se rechazaba no sólo la concreta dirección hacia la que en aquel momento transitaba la política religiosa del Estado español, sino que se negaba la legitimidad misma de la República, a la que se culpaba de todos los males. ${ }^{7}$ Sin embargo, la reacción mayoritaria fue moderada. En síntesis, se reconocía la legitimidad del nuevo orden político. Sin duda el Concilio Vaticano II estaba todavía muy lejos -no sólo en el tiempo, sino en la mentalidad de los eclesiásticos- y la doctrina oficial de la Iglesia católica continuaba propugnando la confesionalidad del Estado como situación ideal, al tiempo que se excluía la separación entre Iglesia y Estado. Pero, con un cauteloso y realista sentido político, se aceptaba como inevitable el nuevo estado de cosas. Se confiaba en que, con el tiempo, sería posible abrir nuevos caminos, dentro del orden constitucional republicano, que permitieran una mejora de la situación de la Iglesia e incluso una nueva norma concordada del Estado con la Santa Sede. ${ }^{8}$

6 Así, uno de los miembros del gobierno provisional de la República, Lerroux, perteneciente al Partido Radical, escribía años más tarde: "La Iglesia no había recibido con hostilidad a la República. Su influencia en un país tradicionalmente católico era evidente. Provocarla a luchar apenas nacido el nuevo régimen era impolítico e injusto; por consiguiente, insensato; y lo hubiera sido en cualquier momento". Y añade a continuación que la guerra civil "espiritualmente quedó encendida en las hogueras del 10 de mayo" [se refiere al 10 de mayo de 1931, menos de un mes después de proclamarse la Segunda República] (La pequeña historia, Buenos Aires, 1945, p. 109).

7 Los dos personajes más representativos, y más influyentes, de esta posición fueron el cardenal Pedro Segura, arzobispo de Toledo (sede primado de España), y Mateo Múgica, arzobispo de Vitoria. Respecto al primero de ellos, el gobierno provisional hizo de su renuncia una cuestión de Estado, y la conseguiría a finales de septiembre de 1931, confiando la Santa Sede en que eso mitigaría los ánimos antes de los debates constitucionales sobre la cuestión religiosa, un par de semanas más tarde. El obispo Múgica había sido exiliado en mayo de 1931.

8 El caso más significado era el del cardenal Francesc Vidal i Barraquer, arzobispo de Tarragona, quien, en estrecha relación con el nuncio pontificio Tedeschini, y con el entonces secretario de Estado del Vaticano, Eugenio Pacelli, tendría una importante influencia para suscitar una actitud de moderación en el episcopado español. En relación con las distintas posiciones políticas de la jerarquía eclesiástica española al inicio de la Segunda República, véase Cárcel Ortí, V., La persecución religiosa..., cit., pp. 98-128; y Redondo, G., Historia de la Iglesia..., cit., pp. 131-158. 
Es importante, por lo demás, no perder de vista el contexto de la época cuando se examinan las actitudes extremas adoptadas a favor o en contra de la Iglesia católica. Sin duda esas actitudes nos parecen excesivas, y difícilmente justificables desde la perspectiva que, ahora, nos otorgan casi setenta años de evolución política en occidente. Pero no resultan incomprensibles si atendemos a las coordenadas históricas y culturales en que se sitúan.

Así, por lo que se refiere a las actitudes antieclesiásticas, no podemos olvidar que, como en un movimiento de péndulo, intentaban actuar de contrapeso frente al secular - y abusivo - predominio de la Iglesia católica en la política, la educación y la cultura en España. Es frecuente que se hiciera alusión a la influencia eclesiástica como peso muerto que lastraba el progreso de España en todos los órdenes; y en ello hay mucho de simplificación histórica, pero también bastante de verdad ${ }^{9}$ (de hecho, la propia Iglesia iría abandonando muchas de sus prevenciones atávicas unos años más tarde). Por otro lado, la izquierda española — como en general la izquierda europea — todavía estaba fascinada por el socialismo comunista soviético (y sorprendentemente lo estaría por mucho tiempo), con los ojos velados ante el horror estalinista, todavía en pleno desarrollo. Además, Europa aún no había sufrido la segunda guerra mundial, ni era posible todavía entender adecuadamente lo que la noción de derechos humanos aportaría a la conciencia jurídica internacional.

Por su parte, las posiciones eclesiásticas decididas a mantener a ultranza la confesionalidad del Estado no pueden extrañar en una jerarquía habituada a una estrecha y privilegiada cooperación con los poderes públicos, y en una Iglesia católica que aún no había dado el salto doctrinal que supuso el Concilio Vaticano II, el cual, para lo que aquí interesa, recuperó la sensibilidad hacia la necesaria independencia de la Iglesia respecto al Estado, e introdujo en el ámbito católico la noción de libertad religiosa y libertad de las conciencias. En ese contexto es explicable que, en algunos eclesiásticos, pesara mucho la visión idílica de un ancien

\footnotetext{
9 Vale la pena citar aquí unas palabras de Salvador de Madariaga, persona de merecido prestigio intelectual, con raíces en la Institución Libre de Enseñanza, que llegaría a ser ministro de Instrucción Pública de la República en 1934: “[...] los defectos de la Iglesia española, y en particular la incultura de la masa que bajo su manto se cobija, se deben no a ser católica, sino a ser española, es decir, a que la Iglesia católica [...] ha acompañado al resto de España en su decadencia e incultura", Anarquía o jerarquía (ideario para la Constitución de la II República Española), Madrid, 1935, p. 218).
} 
régime como brazo secular de los intereses de la Iglesia. De hecho, la defensa de la fe católica como signo de identidad nacional estaba entonces muy presente en el episcopado español, y afloraría más tarde con renovada fuerza al término de la guerra civil en 1939. Simultáneamente, la violencia antirreligiosa permitida $-\mathrm{y}$ a veces instigada - en determinados momentos contra bienes y personas serviría de argumento ad hominem para reafirmar a los eclesiásticos más radicales en sus convicciones antirrepublicanas.

Si se me permite una discreta simplificación de la historia, puede afirmarse que, por lo que respecta a la cuestión religiosa, los primeros meses de vida de la Segunda República se caracterizan por la tensión entre las posiciones radicales y las posiciones moderadas. Entre éstas, ya fueran más favorables a mantener o a eliminar, respectivamente, los privilegios tradicionales de la Iglesia católica, era posible un entendimiento a pesar de sus desacuerdos. De hecho, hubo reiterados intentos en esa línea, incluyendo la busca de una nueva norma concordada o, al menos - era la posición de Fernando de los Ríos- un modus vivendi con la Santa Sede. ${ }^{10}$ Sin embargo, en la redacción del texto constitucional terminaron por triunfar las actitudes radicales de signo anticatólico, pese a que no parecían muy representativas de las fuerzas sociales mayoritarias.

Aunque en sus líneas generales son suficientemente conocidos, conviene recordar algunos de los hechos centrales de ese proceso, que conduciría a la aprobación del artículo 26 de la Constitución de 1931, y más tarde, inspirado por él, a la promulgación de la Ley de Confesiones y Congregaciones Religiosas de 1933.

\section{LA POLÍTICA RELIGIOSA DEL GOBIERNO PROVISIONAL}

Como se ha dicho acertadamente, ${ }^{11}$ el gobierno provisional que proclamó la República el 14 de abril de 1931 no tenía una noción unánime y definida de cómo había de enfocarse la política en materia religiosa y, en particular, en relación con la Iglesia católica. Lo cual resultaba explicable por la heterogeneidad de las posiciones personales que, en esos

10 Véase Vázquez García-Peñuela, J. M., El intento concordatario de la Segunda República (1933-1935), Madrid, 1999, especialmente pp. 46-53 y ss.

11 Cfr. Meer, F. de, La cuestión religiosa..., cit., p. 24. 
temas, caracterizaba a los miembros del gabinete (aunque la mayoría presentaba un talante irreligioso, y a veces anticatólico, de características diversas). ${ }^{12}$ El hecho es que, más que objetivos precisos, sólo compartían algunos postulados básicos respecto a los cambios que era necesario introducir en los planteamientos tradicionales del Estado español.

Esos cambios consistían principalmente en la instauración de la libertad de cultos y creencias, ${ }^{13}$ y en la separación de la Iglesia y el Estado, con la consiguiente secularización de las instituciones públicas y el establecimiento de la enseñanza laica. El núcleo de atención, naturalmente, no era la regulación de los aspectos individuales de la libertad religiosa, o de la vida de las confesiones religiosas en general, sino el estatuto jurídico de la Iglesia católica, dada la estructura socio-religiosa del país.

En congruencia con los principios mencionados, el gobierno provisional dictó en mayo de 1931 algunas normas, ${ }^{14}$ entre las que tuvieron singular relevancia el decreto sobre voluntariedad de la enseñanza religiosa en las escuelas públicas, ${ }^{15}$ y el decreto sobre libertad de cultos. ${ }^{16}$ En el primero se eliminaba la obligatoriedad de la enseñanza religiosa — católica, que era la única impartida — para aquellos alumnos cuyos padres no la solicitaran expresamente. En el segundo, se reconocía a

12 El presidente del gobierno provisional era Niceto Alcalá Zamora (Derecha Liberal). Las diferentes carteras ministeriales se repartían como sigue: Estado: Alejandro Lerroux (Radical); Justicia: Fernando de los Ríos (Socialista); Guerra: Manuel Azaña (Acción Republicana); Marina: Santiago Casares Quiroga (Organización Republicana Gallega); Gobernación: Miguel Maura (Derecha Liberal); Economía: Nicolau D’Olwer (Esquerra); Instrucción Nacional: Marcelino Domingo (Radical-Socialista); Trabajo: Francisco Largo Caballero (Socialista); Hacienda: Indalecio Prieto (Socialista); Comunicaciones: Diego Martínez Barrio (Radical). Los únicos miembros católicos — con una concepción liberal del catolicismo- eran Alcalá Zamora y Miguel Maura, aunque Fernando de los Ríos se había definido en alguna ocasión como "católico erasmista". Los demás miembros del gabinete - algunos de los cuales eran masones, con mayor o menor grado de compromiso personal - adoptaban posiciones que iban desde una irreligiosidad no beligerante a la declarada hostilidad antirreligiosa, y especialmente anticatólica.

13 La libertad de creencias y cultos se incluía — artículo 3o.- en el Estatuto jurídico que se otorgó el propio gobierno provisional para definir los principios fundamentales de su política: "El Gobierno provisional hace pública su decisión de respetar de manera plena la conciencia individual mediante la libertad de creencias y cultos, sin que el Estado en momento alguno pueda pedir al ciudadano revelación de sus convicciones religiosas".

14 Véase Meer, F. de, La cuestión religiosa..., cit., pp. 39-51.

15 Decreto de 6 de mayo de 1931, del Ministerio de Instrucción Pública. Sus responsables fueron Marcelino Domingo y Rodolfo Llopis, ministro de Instrucción Pública y director general de Primera Enseñanza respectivamente.

16 Decreto de 23 de mayo de 1931, del Ministerio de Justicia, que respondía plenamente a las ideas del ministro Fernando de los Ríos. 
todas las confesiones el derecho al culto privado y público, y se determinaba que ninguna persona estaba obligada a manifestar su religión por razón de su relación con órganos del Estado, y que ningún funcionario estatal tenía el deber de participar en ceremonias religiosas en función de su cargo. En los meses de mayo y junio, otras normas incidieron en la secularización de instituciones estatales: se suprimió el derecho de los prelados a pertenecer al Consejo de Instrucción Pública, se consintieron los símbolos religiosos únicamente en las escuelas donde la totalidad de los padres de alumnos lo solicitaran, y se eliminó la celebración de ciertas festividades religiosas en el Ejército, así como la obligatoriedad de la asistencia a misa en establecimientos militares. Además, se impusieron ciertas restricciones a la enajenación de bienes eclesiásticos con el objeto de proteger el patrimonio artístico y cultural español.

Con independencia del juicio que pueda merecer el contenido concreto de esas medidas desde una perspectiva actual —no parecen ahora especialmente atentatorias contra la libertad religiosa-, es interesante hacer notar que se criticó entonces el hecho mismo de que fueran adoptadas por un gobierno provisional, antes de que las Cortes constituyentes se pronunciaran al respecto. Sobre todo, teniendo en cuenta que esas normas iban en contra del Concordato de 1851 con la Santa Sede, entonces todavía vigente, el cual no era ni siquiera aludido en disposición normativa alguna, sino simplemente ignorado (lo cual propició que, tanto por parte del gobierno como por parte de la Santa Sede, terminara por considerarse decaído, sobre todo tras la promulgación de la Constitución, pese a no haberse formulado denuncia formal del mismo). ${ }^{17}$

Sea como fuere, en paralelo a esas disposiciones secularizadoras, el clima de las relaciones entre la Iglesia católica y el gobierno provisional

\footnotetext{
17 Véase Redondo, G., Historia de la Iglesia..., cit., pp. 184-186. Debe recordarse que, en su discurso de 8 de octubre de 1931 ante las Cortes constituyentes, abriendo el debate sobre la cuestión religiosa (véase infra epígrafe 4 de este trabajo), el entonces ministro de Justicia Fernando de los Ríos indicaba que el gobierno "coincidió plenamente" cuando él había leído una nota al Consejo de Ministros en la que "el Concordato se consideraba caducado" (cfr. Extracto Oficial de las Sesiones de las Cortes Constituyentes, 8 de octubre de 1931, p. 3). Por otro lado, es significativo que, se ha advertido oportunamente, la Santa Sede no apelara "a la vigencia del Concordato de 1851 como salvaguardia o parapeto defensivo de los derechos de la Iglesia en España”, en ningún momento de los avatares de la política religiosa de la Segunda República (sí lo hizo, en cambio, el episcopado español: véase infra, notas 20-21 y texto correspondiente). "La causa es que no tenía ningún apego a dicho Concordato", sobre todo por razón del derecho de patronato (Vázquez García-Peñuela, J. M., El intento concordatario de la Segunda República, cit., p. 19.
} 
se iba enrareciendo progresivamente. Dos factores alimentaron especialmente las tensiones. En primer lugar, la consternación social producida por los incendios de edificios religiosos y otros desórdenes provocados contra instituciones eclesiásticas, que fueron enfrentados por el gobierno, y por diversas autoridades locales, con una relativa pasividad (hasta cierto punto causada por su temor a atraerse la antipatía de las posiciones más radicales de algunos partidos de izquierda, que en gran medida instigaron esos desórdenes). ${ }^{18}$ En segundo lugar, la drástica reacción del Cardenal Segura ${ }^{19}$ contra la política gubernamental, que iba acompañada de una declarada simpatía por el caído régimen monárquico.

Las actuaciones del Cardenal de Toledo produjeron una creciente tirantez entre Iglesia y gobierno. Segura no representaba el sentir mayoritario del alto clero español. Pero su posición de primado, unida a los recelos que iban despertando ciertas actitudes de tolerancia gubernamental hacia la violencia antirreligiosa, hizo que influyera en determinados comportamientos del episcopado, no obstante la acción neutralizadora de personas más prudentes, como el cardenal de Tarragona, Vidal i Barraquer, el director del diario católico El Debate, Ángel Herrera, y el propio nuncio de la Santa Sede, Tedeschini.

Particularmente importante fue su influencia en la conferencia de metropolitanos celebrada en Toledo el 9 de mayo, de la cual saldría una carta colectiva $^{20}$ en la que los obispos se mostraban opuestos al proceso de desconfesionalización del Estado español, considerando que el go-

18 En relación con los episodios de violencia antieclesiástica, véase Cárcel Ortí, V., La persecución religiosa en España durante la Segunda República, cit., especialmente pp. 109 y ss.; y Martí Gilabert, F., Política religiosa de la Segunda República española, cit., pp. 38 y ss. El entonces presidente del Gobierno, Alcalá Zamora, juzga duramente esos abusos violentos en sus escritos posteriores, indicando que sus consecuencias "para la República fueron desastrosas: le crearon enemigos que no tenía; mancharon un crédito hasta entonces diáfano e ilimitado; quebrantaron la solidez compacta de su asiento; motivaron reclamaciones de países tan laicos como Francia o violentas censuras de los que, como Holanda, tras haber execrado nuestra intolerancia antiprotestante, se escandalizaban de la anticatólica” (Memorias, Barcelona, 1977, p. 185).

19 Pedro Segura era arzobispo de Toledo y cardenal primado de España.

20 La conferencia de metropolitanos había acordado que esa carta colectiva, que llevaba fecha de 3 de junio de 1931, sería enviada de manera rigurosamente privada por el cardenal Segura al presidente del Gobierno, Alcalá Zamora. Segura, sin embargo, la hizo pública, y añadió así un elemento adicional de tensión a las relaciones entre Estado e Iglesia. Antes y después de esa conferencia de arzobispos, el gobierno provisional se había sentido indignado por dos cartas pastorales escritas a título personal por el cardenal Segura, fechadas el 1 mayo y el 25 julio. Véase Redondo, G., Historia de la Iglesia en España, cit., pp. 135-145. 
bierno republicano había agraviado los derechos de la Iglesia amparados por el Concordato. ${ }^{21}$

El gobierno provisional exigió a partir de agosto, sin concesiones, la renuncia del cardenal Segura. El tour de force se prolongó durante todo el verano de 1931, y concluiría con la renuncia "voluntaria" de Segura a finales de septiembre. Un elemento decisivo para lograr esa renuncia fueron las intervenciones de Vidal i Barraquer, cuya actitud moderada propiciaba un mayor entendimiento con el gobierno republicano, y que perseguía una distensión de las relaciones entre poder religioso y poder civil antes de que se iniciara el debate constitucional sobre la cuestión religiosa. ${ }^{22}$

Vidal i Barraquer, de hecho, junto con el nuncio Tedeschini, mantuvo en el mismo mes de septiembre algunas reuniones con el presidente del Gobierno, Niceto Alcalá Zamora, y con los ministros Alejandro Lerroux (Estado) y Fernando de los Ríos (Justicia). En ellas se acordó otorgar a la Iglesia católica un estatuto jurídico bastante razonable, que resultara compatible con la transformación del Estado que pretendía el gobierno republicano. Lo cual incluía el respeto de las órdenes religiosas, la libertad de enseñanza, ayuda económica, e incluso — con posterioridad a la promulgación de la Constitución - la posibilidad de un concordato, precedido de un modus vivendi. ${ }^{23} \mathrm{El}$ problema es que el resto del gabinete

21 En esa carta se contenía una precisa lista de agravios. Es significativo comprobar que casi todos ellos son admitidos hoy como algo completamente normal en un Estado, como el español, que no se pronuncia constitucionalmente a favor del separatismo, sino que se presenta desde 1978 como inspirado en los principios de libertad religiosa, neutralidad, igualdad y cooperación con las confesiones religiosas. Así, por ejemplo, entre los agravios enumerados se mencionan los siguientes: la libertad de cultos ("que vulnera leyes fundamentales del Estado y artículos sustanciales del Concordato"); la eliminación de la enseñanza religiosa obligatoria en las escuelas públicas; la secularización de cementerios; la supresión de honores militares al Santísimo Sacramento a su paso por las calles ("según el uso y ley tradicional de la España católica"); o las normas proteccionistas de los bienes de valor artístico ("que lesiona[n] derechos inviolables de la Iglesia sobre sus propios bienes").

22 Vidal i Barraquer, en efecto, presionó ante Eugenio Pacelli, entonces secretario de Estado del Vaticano, haciéndole ver que, en vísperas del debate constitucional, no quedaba otro remedio que la renuncia de Segura si se quería asegurar una mejor disposición del gobierno hacia la Iglesia católica. De hecho, en aquel momento la cuestión religiosa ya había comenzado a ser abordada durante los debates sobre la totalidad del proyecto de Constitución, que habían tenido lugar desde el 27 de agosto hasta el 11 de septiembre (véase Redondo, G., Historia de la Iglesia en España..., cit., pp. 153-158).

23 Alcalá y Lerroux aceptaban el concordato. Fernando de los Ríos, en cambio, insistía en esperar a la Constitución, y en no proceder directamente a la negociación de un concordato, sino comenzar por un modus vivendi. Véase Meer, F. de, La cuestión religiosa..., cit., pp. 117-127; Redondo, G., Historia de la Iglesia..., cit., pp. 154-158. 
ministerial no parecía dispuesto a aceptar ningún compromiso con la jerarquía eclesiástica que limitara la autonomía de las Cortes constituyentes. Y éstas, como indicaré enseguida, decidieron seguir un camino bien distinto.

\section{PREPARACIÓN Y APROBACIÓN DEL ARTÍCULO 26 DE LA CONSTITUCIÓN}

En esa atmósfera política y social que tan sucintamente ha sido descrita, tuvieron lugar los trabajos de las Cortes constituyentes. Éstas fueron elegidas el 28 de junio de 1931, sin que, curiosamente, en la campaña electoral la cuestión religiosa ocupara un lugar de relevancia, con algunas excepciones. Por diversas circunstancias - entre ellas la escasa percepción de la singularidad del momento histórico que tuvieron las fuerzas políticas de inspiración católica - la representación parlamentaria del catolicismo real de la sociedad española era escasa, y sobre todo desproporcionada. $^{24}$

El gobierno había encargado a la Comisión Jurídica Asesora, presidida por Ângel Ossorio y Gallardo, la elaboración de un anteproyecto de Constitución de la República. El anteproyecto fue entregado a principios de julio, y en él trataba de resolverse la cuestión religiosa mediante un equilibrio entre la libertad religiosa propia de un Estado secularizado y el respeto del peso histórico y social de la Iglesia católica. Así, a semejanza de la Constitución de Weimar, no se establecía una religión oficial del Estado, pero la Iglesia católica era considerada corporación de derecho público, abriendo esa posibilidad también a las demás confesiones; se reconocía la libertad de conciencia y el derecho a la práctica privada y pública del culto; y se garantizaba el derecho de los escolares a recibir enseñanza religiosa junto con el derecho del maestro a no impartirla contra su conciencia. ${ }^{25}$

24 Los tres partidos mayoritarios eran el socialista, el radical y el radical-socialista. Este último había hecho de las medidas antieclesiásticas uno de los argumentos de su campaña electoral. Véase Meer, F. de, La cuestión religiosa..., cit., pp. 59 y ss.

25 El gobierno provisional había creado la Comisión Jurídica Asesora por decreto de 6 de mayo de 1931, para sustituir a la Comisión General de Codificación, disuelta en el mismo decreto; sus miembros, entre los que figuraban insignes juristas de la época, fueron nombrados por otro decreto de 9 de mayo, a propuesta del ministro de Justicia. Véase Arbeloa, V. M., "Iglesia y Estado en el anteproyecto de Constitución de 1931”, Revista Española de Derecho Canónico (1971), 
El anteproyecto no fue bien recibido ni por amplios sectores católicos, que lo consideraban lesivo para los intereses de la Iglesia, ni por el gobierno, que no lo hizo suyo y renunció a presentarlo como ponencia a las Cortes constituyentes. ${ }^{26}$ Las Cortes, por tanto, nombraron una comisión que elaborase un nuevo proyecto de Constitución.

La Comisión Constitucional, compuesta por 21 diputados bajo la presidencia del socialista Jiménez de Asúa, ${ }^{27}$ se constituyó el 28 de julio, y tardó veinte días en tener listo su proyecto (publicado oficialmente el 18 de agosto). En materia religiosa se adoptaba un planteamiento bien diferente del que inspiraba el anteproyecto elaborado por la Comisión Jurídica, anticipando lo que sería la línea dominante en el texto constitucional definitivo. La Iglesia católica era incluso tratada con mayor du-

pp. 313 y ss.; Meer, F. de, La cuestión religiosa..., cit., pp. 62-65. La influencia alemana resultaba particularmente chocante en el hecho de establecer que no existía "religión de Estado": lo cual no tenía mucho sentido en España, donde nunca había existido una Iglesia de Estado según el modelo protestante. Más correcto hubiera sido indicar — como finalmente haría el artículo 3o. de la Constitución que el Estado se declaraba aconfesional. Vale la pena reproducir parte del anteproyecto, algunos de cuyos artículos inspirarían el texto constitucional definitivamente aprobado (especialmente el artículo 27).

Artículo 8: "No existe religión de Estado. La Iglesia católica será considerada como Corporación de Derecho Público. El mismo carácter podrán tener las demás confesiones religiosas cuando lo soliciten y, por su constitución y el número de sus miembros, ofrezcan garantías de subsistencia". Artículo 12: "La libertad de conciencia y el derecho de profesar y practicar libremente cualquier religión, quedan garantizados en el territorio español, salvo el respeto debido a las exigencias de la moral pública. Todas las confesiones podrán ejercer sus cultos, privada y públicamente, sin más limitaciones que las impuestas por el orden público. Nadie podrá ser compelido a declarar oficialmente sus creencias religiosas a no ser por motivos estadísticos. La condición religiosa no constituirá circunstancia modificativa de la personalidad civil ni política, excepto lo dispuesto en el artículo 54, apartado c), de esta Constitución".

Artículo 31: “[...] El escolar tiene derecho a la enseñanza religiosa, pero el maestro no puede ser obligado a prestarla contra su conciencia”.

26 Es interesante hacer notar que la Comisión Jurídica Asesora, a través de su Subcomisión del Estatuto de Relaciones entre la Iglesia y el Estado, llegaría también a elaborar un proyecto de "Estatuto del régimen público de la Iglesia Católica en España", que lleva fecha de 23 de septiembre de 1931, y consta como enviado "directamente, con carácter reservado, al Sr. Ministro de Justicia" (Fernando de los Ríos). El texto, inédito hasta ahora, ha sido descubierto, y comentado, por Vázquez García-Peñuela, J. M., El intento concordatario..., cit. La influencia germana continuaba haciéndose notar en ese proyecto de estatuto, que contemplaba la implantación de un impuesto eclesiástico al estilo alemán.

27 La distribución de los miembros era la siguiente: cinco socialistas, cuatro radicales, tres radical-socialistas, un agrario (Gil Robles, católico) y un vasco. Una descripción detallada de los miembros de la Comisión, y de su trabajo, puede verse en Arbeloa, V. M., "El proyecto de Constitución de 1931 y la Iglesia”, Revista Española de Derecho Canónico (1976), pp. 87 y ss. 
reza que en la redacción final del artículo 26 de la Constitución, pues se preveía la disolución de todas las órdenes religiosas — no sólo los jesuitas-, cuyos bienes habrían de ser nacionalizados. ${ }^{28}$

Sobre ese texto se desarrollaron las discusiones parlamentarias, tanto sobre la totalidad del proyecto (desde el 27 de agosto al 11 de septiembre), como sobre el estatuto jurídico de la Iglesia católica y de las órdenes religiosas (del 8 al 14 de octubre). Naturalmente, no es éste el lugar adecuado para una relación detallada de lo sucedido en esos momentos de nuestra historia constitucional, ${ }^{29}$ pero sí vale la pena describir cuáles fueron los principales protagonistas del juego parlamentario, y el resultado final a que se llegó.

Los debates de las Cortes sobre la cuestión religiosa revelaron el enfrentamiento entre las posiciones moderadas y extremistas. ${ }^{30}$ Estas últimas fueron sostenidas, en la discusión y en las votaciones, por las tres grandes fuerzas de izquierda: los partidos socialista, radical-socialista y radical. La declaración de hostilidad hacia la Iglesia católica quedaba

28 Reproduzco a continuación los artículos más significativos del proyecto en relación con la cuestión religiosa:

Artículo 30.: "No existe religión del Estado".

Artículo 24: “Todas las confesiones religiosas serán consideradas como Asociaciones sometidas a las leyes generales del país. El Estado no podrá, en ningún caso, sostener, favorecer ni auxiliar económicamente a las Iglesias, Asociaciones e Instituciones religiosas. El Estado disolverá todas las Órdenes religiosas y nacionalizará sus bienes".

Artículo 25: "La libertad de conciencia y el derecho de profesar y practicar libremente la religión quedan garantizados en el territorio español, salvo el respeto debido a las exigencias de la moral pública. Las confesiones religiosas sólo podrán ejercer sus cultos en sus respectivos templos, sin más limitaciones que las impuestas por el orden público. Nadie podrá ser compelido a declarar oficialmente sus creencias religiosas. La condición religiosa no constituirá circunstancia modificativa de la personalidad civil ni política, salvo lo dispuesto en esta Constitución para el nombramiento del Presidente de la República”.

Artículo 46: “[...] La enseñanza será laica. Se reconoce a las Iglesias el derecho, sujeto a inspección del Estado, a enseñar sus respectivas doctrinas en sus propios establecimientos".

29 Una detallada narración de los debates, y del contexto socio-político en el que deben situarse, puede verse en Meer, F. de, La cuestión religiosa..., cit., pp. 87-195; véase también Astarloa, F., Región y religión en las Cortes constituyentes de 1931, Valencia, 1976, pp. 137-158. A esos trabajos me remito para las citas de las intervenciones que mencionaré a continuación.

30 Es significativo que el apasionamiento que suscitaba el debate sobre la cuestión religiosa llegara a afectar a la cuestión de los derechos de voto de las mujeres. Al discutir la igualdad de derechos electorales de los ciudadanos españoles, sin distinción de sexos (artículo 36), algunos sectores de la izquierda manifestaron una tenaz resistencia a conceder igualdad de derecho a voto a las mujeres, por presumir que eran más sensibles a la influencia clerical y que, por tanto, serían una fuerza reaccionaria y antirrepublicana (véase Martí Gilabert, F., Política religiosa de la Segunda República..., cit., pp. 107-108). 
patente ya desde el discurso de Jiménez de Asúa introduciendo el proyecto de Constitución antes del debate sobre la totalidad. En sus palabras de presentación, insistía en la oposición — artificiosa - entre la idea republicana y el estamento eclesiástico. Intervenciones posteriores de representantes de esos tres partidos, sobre todo con ocasión del artículo $26,{ }^{31}$ confirmarían la irreductible firmeza de esas actitudes.

Como contrapartida, las intervenciones de los diputados católicos se obstinaron con frecuencia en defender, contra todo pronóstico razonable, el mantenimiento de los derechos históricos de la Iglesia desde una perspectiva de rigurosa conformidad con el ius publicum ecclesiasticum (de hecho, algunos de esos diputados eran sacerdotes). De entre los sectores católicos, probablemente fue Gil Robles el único que adoptó una posición más realista, y más mesurada, atacando el proyecto de Jiménez de Asúa en un doble frente. Por un lado, subrayaba la necesidad de reconocer la autonomía de la Iglesia católica para el cumplimiento de sus fines propios. Por otro, advertía en que la propuesta de disolución de las órdenes religiosas no sólo iba en contra de la libertad religiosa, sino también en contra del principio de igualdad y del derecho de asociación (que ya habían sido aprobados por las Cortes). Aun así, la actitud final de Gil Robles fue de rechazo del proyecto en bloque, sin aprovechar los resquicios para la negociación que el discurso que el ministro de Justicia había ofrecido antes.

En efecto, Fernando de los Ríos fue el encargado de abrir el debate sobre la cuestión religiosa, pero lo hizo en nombre propio, en tanto que ministro de Justicia. No representaba la posición del gobierno, que carecía de criterio homogéneo al respecto, ni tampoco la postura oficial del Partido Socialista, al que pertenecía, pero respecto al cual mantenía ideas contrastantes en esta materia. En su intervención defendió los criterios que había mantenido durante sus meses como ministro. En especial, acentuó la importancia de que el Estado fuera aconfesional, y de que se estableciera un régimen de separación entre Estado e Iglesia. De lo cual se derivaba que la Iglesia católica no debía recibir ayuda económica del Estado, y que tampoco podía ser considerada una corporación de derecho público. Por otra parte, no juzgaba oportuno negociar de momento un concordato: primero, el Estado debería definir unilateral-

31 En el proyecto presentado por la Comisión de Constitución, era inicialmente el artículo 24, pero pasaría más tarde a ser el artículo 26. 
mente la posición jurídica de la Iglesia, y después podría procederse a la firma de un modus vivendi. Por lo demás, se manifestó contrario a la proyectada disolución de las órdenes religiosas, sugiriendo que había llegado el momento de poner fin a las tradicionales eliminaciones del adversario religioso que habían caracterizado la política española desde la expulsión de los judíos en 1492.

No faltaron otras intervenciones moderadas por parte de personas de relieve de procedencia liberal, tanto durante los debates a la totalidad del proyecto de Constitución como durante los debates sobre la cuestión religiosa en concreto. Entre ellas cabe destacar las de Zulueta, Ortega y Gasset, y el propio presidente del Gobierno Alcalá Zamora. Este último, sin embargo, se quedó virtualmente solo en su defensa de la libertad de conciencia desde su perspectiva de católico liberal, y no obtuvo el apoyo ni de los partidos de matriz católica ni de los de izquierda. Además, intelectuales como Gregorio Marañón se pronunciaron, en la víspera de la discusión definitiva sobre el artículo 26, en favor de un mayor respecto hacia las instituciones eclesiásticas, evitando gestos inmoderados o revanchistas.

El clima de las discusiones sobre la cuestión religiosa en sus primeros días determinó que la Comisión de Constitución, el día antes de concluir el debate sobre esta materia, decidiera modificar la redacción del artículo 26, es decir, el artículo relativo a las confesiones religiosas, que era sin duda el que planteaba problemas más espinosos. Sobre la base de las enmiendas presentadas por el Partido Radical, por Acción Republicana y por Miguel Maura (católico, ministro de Gobernación), y pese a la oposición radical-socialista y a las reticencias socialistas, se mitigó el rigor con que se abordaba el estatuto jurídico —o más bien la supresión- de las órdenes religiosas. No obstante, el texto continuó siendo decididamente restrictivo.

El último de los discursos importantes en esta materia fue el de Manuel Azaña. El entonces ministro de la Guerra realizó una elocuente apología del texto recién enmendado, al que, sin embargo, proponía añadir algunos matices antieclesiásticos. En particular, sugería que se incluyera en el propio texto constitucional ${ }^{32}$ la disolución de la orden que más estaba en el punto de mira de los embates anticatólicos: la Compañía

32 En lugar de remitirlo a la futura ley de confesiones religiosas, como constaba en el artículo recién modificado por la Comisión. 
de Jesús; ${ }^{33}$ y abogaba por que se prohibiera a las órdenes religiosas continuar ejerciendo la enseñanza. Su intervención sería decisiva para fijar el tenor definitivo del artículo 26 de la Constitución.

Éste fue aprobado, tras una noche de debates, a las 7.35 horas de la mañana del 14 de octubre, con la abstención de los radical-socialistas, contrarios a toda reforma de la redacción primigenia del proyecto, más extrema. Vale la pena reproducir aquí su texto íntegro, que es lo suficientemente expresivo como para requerir ulterior comentario:

Todas las confesiones religiosas serán consideradas como Asociaciones sometidas a una ley especial.

El Estado, las Regiones, las Provincias y los Municipios no mantendrán, favorecerán ni auxiliarán económicamente a las Iglesias, Asociaciones e Instituciones religiosas.

Una ley especial regulará la total extinción, en un plazo máximo de dos años, del presupuesto del clero.

Quedan disueltas aquellas Órdenes religiosas que estatutariamente impongan, además de los tres votos canónicos, otro especial de obediencia a autoridad distinta de la legítima del Estado. Sus bienes serán nacionalizados y afectados a fines benéficos y docentes.

Las demás Órdenes religiosas se someterán a una ley especial votada por estas Cortes Constituyentes y ajustada a las siguientes bases:

$1^{a}$. Disolución de las que, por sus actividades, constituyan un peligro para la seguridad del Estado.

$2^{a}$. Inscripción de las que deban subsistir en un registro especial dependiente del Ministerio de Justicia.

$3^{a}$. Incapacidad de adquirir y conservar, por sí o por persona interpuesta, más bienes de los que, previa justificación, se destinen a su vivienda o al cumplimiento directo de sus fines privativos.

$4^{a}$. Prohibición de ejercer la industria, el comercio o la enseñanza.

$5^{\text {a }}$. Sumisión a todas las leyes tributarias del país.

$6^{a}$. Obligación de rendir anualmente cuentas al Estado de la inversión de sus bienes en relación con los fines de la Asociación.

Los bienes de las Órdenes religiosas podrán ser nacionalizados.

33 Posteriormente, Azaña afirmaría — no está claro si a modo de explicación o a modo de excusa- que la disolución de los jesuitas era necesaria, a modo de carnaza que posibilitara el desahogo de los diputados anticlericales, y evitara males mayores ( $c f r$. Martí Gilabert, F., Política religiosa..., cit., p. 110). 
El artículo 27 de la Constitución, en el que se regulaba la libertad religiosa, fue aprobado al día siguiente, 15 de octubre, tras un breve debate, con un texto en el que se apreciaban notables contradicciones con lo dispuesto en el artículo 26. Se garantizaba la libertad de conciencia y el derecho a la libre práctica de cualquier religión, con el límite de la moral pública, y se declaraba que la condición religiosa no constituiría circunstancia modificativa de la personalidad civil o política. Se secularizaban los cementerios. Y se condicionaban las manifestaciones públicas del culto religioso a una autorización gubernativa ad casum. ${ }^{34}$

Se producía así una notable esquizofrenia constitucional al regular la cuestión religiosa. Por un lado, se afirmaba genéricamente la libertad religiosa y de conciencia. Por otro lado, se establecían notables restricciones a su ejercicio concreto, en su vertiente colectiva e institucional. De hecho, no deja de ser significativo que el contenido del artículo 27 fuera colocado después del 26, cuando en buena lógica hubiera debido ser al revés: la enumeración del principio de libertad debería preceder la regulación de las confesiones religiosas. La impresión que se obtiene es que los constituyentes querían libertad, pero para una sociedad distinta de la española de entonces. Por eso comienzan paradójicamente por cercenar la libertad religiosa, en un intento de reforma social y cultural "en vertical", de arriba a abajo.

Por su parte, el artículo 3o., aprobado el 13 de octubre, había delimitado el marco constitucional de la aconfesionalidad del Estado: "El Estado español no tiene religión oficial". Y el artículo 48, aprobado el 28 de octubre, confirmaba la laicidad de la enseñanza en España, de manera que las confesiones religiosas sólo podrían enseñar "sus respectivas doctrinas en sus propios establecimientos". ${ }^{35}$

34 Artículo 27: "La libertad de conciencia y el derecho de profesar y practicar libremente cualquier religión quedan garantizados en el territorio español, salvo el respeto debido a las exigencias de la moral pública.

Los cementerios estarán sometidos exclusivamente a la jurisdicción civil. No podrá haber en ellos separación de recintos por motivos religiosos.

Todas las confesiones podrán ejercer sus cultos privadamente. Las manifestaciones públicas del culto habrán de ser, en cada caso, autorizadas por el gobierno.

Nadie podrá ser compelido a declarar oficialmente sus creencias religiosas.

La condición religiosa no constituirá circunstancia modificativa de la personalidad civil ni política, salvo lo dispuesto en esta Constitución para el nombramiento de Presidente de la República y Presidente del Consejo de Ministros" [para esos cargos se excluía a "los eclesiásticos, los ministros de las varias confesiones y los religiosos profesos”: $c f r$. artículos 70 b y 87].

35 Artículo 48: “[...] La enseñanza será laica [...]. Se reconoce a las Iglesias el derecho, sujeto a inspección del Estado, de enseñar sus respectivas doctrinas en sus propios establecimientos”. 


\section{LA LEY DE CONFESIONES Y CONGREGACIONES RELIGIOSAS DE 1933}

El modo como habían concluido los debates constitucionales no permitía presagiar buenos tiempos para la pacificación religiosa en España. ${ }^{36}$ La Constitución de la Segunda República fue promulgada el 9 de diciembre de 1931. Antes, el 14 de octubre, el presidente del Gobierno, Alcalá Zamora, había presentado su dimisión por su disconformidad con la solución dada a la cuestión religiosa en el texto constitucional. ${ }^{37}$ Fue sustituido por Azaña, ${ }^{38}$ quien comenzó a aplicar de inmediato - antes de la promulgación de la Constitución - la prohibición constitucional de ayuda económica del Estado a la Iglesia, mediante una serie de medidas destinadas a la progresiva eliminación del presupuesto estatal de culto y clero.

Durante los dos años siguientes - lo que se ha llamado el "bienio de izquierdas" - el gobierno de Azaña continuó con una política religiosa que, en el mejor de los casos, podía calificarse como poco prudente y poco sensible a los sentimientos de los católicos. ${ }^{39}$ El 24 de enero de 1932 se publicaba el decreto de disolución de la Compañía de Jesús, y comenzaba el éxodo de los jesuitas y la nacionalización de sus bienes. Días antes, el Consejo de Ministros había suspendido por tiempo indefinido el diario El Debate, el principal órgano de prensa del catolicismo

36 Resulta ilustrativo leer el análisis de los debates constitucionales en materia religiosa que escribía el Cardenal Vidal i Barraquer al entonces secretario de Estado del Vaticano, Eugenio Pacelli (véase Redondo, G., Historia de la Iglesia en España..., cit., pp. 164-165).

37 Unos años más tarde, Alcalá Zamora escribiría un duro juicio sobre este aspecto de la Constitución republicana: "Fue el anticlericalismo rabioso, el laicismo intransigente, y algo más, mucho más peligroso: se copió de Méjico el encono en la lucha religiosa, el deseo de convertirla en guerra civil crónica, encarnizada". Y añadía: "Han hecho de la República, más que una sociedad abierta a la adhesión de todos los españoles, una sociedad estrecha, con número limitado de accionistas y hasta con bonos de privilegio de fundador" (Los defectos de la Constitución de 1931, Madrid, 1936, p. 51).

38 Posteriormente, Alcalá Zamora sería elegido presidente de la República, el 10 de diciembre de 1931, y confirmaría a Azaña como primer presidente del Gobierno constitucional.

39 Las normas republicanas pueden encontrarse en la colección Leyes religiosas según los textos oficiales. Concordadas, anotadas y con índices completos, editada por Corazony, Granados y Segovia en Madrid, 1935. Un interesante comentario sobre esa colección de normas puede verse en Vázquez García-Peñuela, J. M., "Noticia sobre una recopilación del derecho eclesiástico de la Segunda República española”, Anuario de Derecho Eclesiástico del Estado 8 (1992), pp. 223 y ss. Véase también una descripción de las principales medidas adoptadas en Martí Gilabert, F., Política religiosa..., cit., pp. 100-140. 
en España. Una serie de medidas relativas a las festividades religiosas y la secularización de cementerios, aunque en abstracto pudieran resultar coherentes con la política de un Estado separatista, tuvieron un efecto provocador en los ambientes católicos, bien por lo extemporáneo de su aprobación, bien por la brusquedad de su aplicación en determinados lugares.

En materia de educación, Fernando de los Ríos, que pasó a ocupar la cartera de Instrucción Pública, se propuso ejecutar rigurosamente las prescripciones constitucionales sobre la laicidad de la enseñanza, pese a la falta de realismo que implicaba — por la carencia de medios personales y materiales - el intento de sustituir tan apresuradamente la enseñanza confesional católica. $\mathrm{Y}$ es que la prohibición constitucional de que las congregaciones religiosas ejercieran la enseñanza no sólo estaba en flagrante contradicción con otros artículos de la Constitución (en especial el art. 49, que abría las puertas a los centros privados de enseñanza), sino que resultaba imposible de cumplir en un futuro próximo. Tan es así, que inmediatamente después de la aprobación del artículo 26 de la Constitución, el Consejo de Ministros había advertido a la Iglesia católica que las instituciones religiosas debían continuar de momento su labor docente, y que su interrupción sería sancionada con la incautación de los edificios correspondientes por el Estado. ${ }^{40}$

Por su parte, el episcopado español trató de adoptar una actitud coordinada frente a las normas constitucionales. En noviembre de 1931, los arzobispos españoles se reunieron en Madrid, y acordaron emitir una declaración colectiva, que lleva fecha de 20 de diciembre. En ella, junto a las protestas por la disolución de los jesuitas, se instaba a los católicos a oponerse a los abusos legislativos de la República, pero siempre dentro del respeto a la autoridad y al orden político legítimamente constituido. La insistencia en este último punto provenía de los recelos —manifestados, un mes antes, en la conferencia de metropolitanos- contra el resurgir de un extremismo integrista y monárquico. Vale la pena indicar que, antes de su publicación, la declaración fue modificada por indicación de la Santa Sede, en el sentido de considerar definitivamente caducado el Concordato de 1851, debido a las "mutaciones radicales" experimentadas por el Estado español (lo cual permitió a la Iglesia católica, por

40 Cfr. Meer, F. de, La cuestión religiosa..., cit., p. 199. 
otro lado, liberarse de la servidumbre del patronato regio, y recuperar la independencia en el nombramiento de obispos). ${ }^{41}$

Debilitado y desprestigiado sobre todo por el fracaso de su política social —en especial la reforma agraria-, el gobierno de Azaña todavía tuvo tiempo, en sus últimos meses, de lograr la aprobación de la Ley de Confesiones y Congregaciones Religiosas, de 2 de junio de 1933, en ejecución de los artículos 26 y 27 de la Constitución.

La idea que impregnaba el entero articulado de esa Ley era limitar la influencia social de la Iglesia católica, sometiéndola para ello a un fuerte control gubernativo, que otorgaba un amplio margen de discrecionalidad a las autoridades civiles. Lo cual era, cuando menos, imprudente. En efecto, incluso dejando a un lado la dudosa legitimidad de esa finalidad desde la perspectiva de los derechos fundamentales garantizados por la propia Constitución, ${ }^{42}$ no parece que, de cara al futuro - si es que la Ley hubiera tenido algún futuro- ése fuera el mejor modo de garantizar el pluralismo religioso en España, pues, aun diseñada ad hoc para la Iglesia católica, la norma debería aplicarse a todas las confesiones religiosas. Conviene detenerse, aunque sea sucintamente, en las principales líneas directrices de su contenido dispositivo.

Una de las primeras cosas que sorprenden a quien se acerca al texto legal es una significativa referencia, en el inicio mismo (artículo 2o.), a que se garantiza tanto "la libertad de conciencia" como "la práctica y la abstención de actividades religiosas". La libertad de no practicar la religión es una parte obvia de la libertad religiosa, y por eso no suele mencionarse explícitamente en un texto legal. Su inclusión en la Ley de 1933 puede obedecer a un doble motivo: bien porque, al estilo de las coetáneas constituciones soviética y mexicana, se deseaban marcar los acentos antirreligiosos de la política gubernamental; o bien porque, debido a la tradicional compenetración entre instituciones religiosas y seculares en España, resultaba conveniente subrayar que el ciudadano

41 La indicación de la Santa Sede provenía de la doctrina sentada por el pontífice Benedicto $\mathrm{XV}$, según la cual los concordatos debían estimarse decaídos cuando los cambios — geográficos o morales- experimentados por los Estados eran tan profundos que no podían ser considerados como la misma persona jurídica con la que se llegó a un acuerdo. Véase Redondo, G., Historia de la Iglesia..., cit., pp. 167-175 y 184-187.

42 Esa finalidad, además, parecía ir en contra de la letra misma de la ley, cuyo art. 2 establecía: "Ningún privilegio ni restricción de los derechos podrá fundarse en la condición ni en las creencias religiosas". 
no estaba obligado, en ninguna circunstancia, a participar en ceremonias religiosas en contra de su conciencia.

Más interesan, en todo caso, otras disposiciones del articulado llamadas a influir con mucha mayor intensidad en el panorama socio-religioso de España. Me limitaré a señalar aquellos aspectos — que, por lo demás, son mayoría - que contrastan de manera más acusada con la conciencia jurídica contemporánea, por su carácter restrictivo de lo que hoy entendemos como dimensión colectiva del derecho fundamental de libertad religiosa.

Así, el culto religioso podía ejercerse libremente sólo dentro de los templos; en otro caso, era necesaria una autorización gubernativa especial (para cuya concesión o denegación la ley no indicaba criterio alguno). ${ }^{43}$ A las entidades religiosas se les prohibía efectuar reuniones o actividades de "carácter político": un término que - aparte de otras consideraciones a la luz de la libertad de asociación y de reunión- podía dar lugar, en el caldeado clima social que se vivía entonces en España, a decisiones administrativas arbitrarias, con graves consecuencias, pues la Ley autorizaba la clausura de establecimientos e incluso la disolución del instituto religioso correspondiente..$^{44}$ La Ley indicaba que las confesiones religiosas podían nombrar libremente a sus ministros de culto, administradores y otros cargos..., pero añadía que debían ser españoles, y que el Estado podía no reconocerlos cuando el nombramiento recayera en persona "peligrosa para el orden o la seguridad del Estado" 45 (lo cual, en aquel momento, bien podía ser interpretado simplemente como persona non grata al gobierno). ${ }^{46}$

Un tema al que la Ley de 1933 dedicaba especial atención era el económico y patrimonial. Por supuesto, se reiteraba la disposición cons-

43 Cfr. artículo 3o.

44 Cfr. artículos 3o. y 23.

45 Cfr. artículo 7o.

46 Recuérdese que en 1931, por manifestar su oposición a las directrices políticas del gobierno provisional y su simpatía por el régimen monárquico, el gobierno había expulsado del país al arzobispo de Vitoria, Mateo Múgica, y exigido a la Santa Sede la renuncia del arzobispo primado de España, cardenal Pedro Segura. Recuérdese también que, en la discusión de la cuestión religiosa en los debates constitucionales, el ministro de Justicia Fernando de los Ríos había defendido la separación entre el Estado y la Iglesia, pero también el derecho de veto del Estado respecto al nombramiento de obispos: un derecho - afirmaba - que "a todo Estado celoso y cuidadoso de sus fines no puede menos de atribuírsele" (citado por Meer, F. de, La cuestión religiosa..., cit., p. 139). 
titucional que prohibía toda ayuda económica de instituciones públicas a las iglesias o instituciones religiosas, ${ }^{47}$ y el sometimiento de éstas a la legislación tributaria común. ${ }^{48}$ Pero además se establecían importantes limitaciones a la posibilidad de adquirir y poseer bienes.

Por ejemplo, la Iglesia católica y sus instituciones sólo podían conservar aquellos bienes necesarios para el servicio religioso. ${ }^{49}$ A las congregaciones religiosas únicamente se les permitía poseer los bienes que "previa justificación, se destinen a su vivienda o al cumplimiento de sus fines privativos" ${ }^{50}$ (todo lo cual dejaba abierta la cuestión de quién, y con arreglo a qué criterios, determinaba lo que resultaba necesario para el servicio religioso o los fines privativos; una cuestión abierta que, de nuevo, no ofrecía muchas garantías en aquel momento de la vida política española). Asimismo, entre la documentación que las órdenes y congregaciones religiosas debían presentar para la inscripción que les otorgaría personalidad jurídica civil, la Ley exigía una "declaración de los bienes aportados a la comunidad por cada uno de sus miembros". Prescripción que cobraba sentido al ponerla en conexión con aquella otra que obligaba a que la congregación restituyera al interesado los bienes aportados si decidía posteriormente abandonar el instituto. ${ }^{51}$

Por otra parte, en los artículos 11 a 18 de la Ley se enumeraban diversas medidas encaminadas a la protección del tesoro artístico español perteneciente a la Iglesia católica. Se trataba sin duda de un fin encomiable, pero que muy probablemente hubiera podido lograrse, incluso con mayor eficacia, recurriendo a medidas más respetuosas con los derechos adquiridos y con las peculiaridades estructurales y funcionales de la Iglesia. Téngase en cuenta que el texto legal decretaba la nacionalización de todos los bienes eclesiásticos, muebles e inmuebles, destinados al culto, al gobierno, a la formación del clero y a vivienda de religiosos. Esos bienes continuarían destinados, en principio, a la misma finalidad religiosa, pero la Iglesia no podía disponer de ellos excepto cuando el Estado le cediera, mediante una ley especial, bienes carentes de suficiente "valor, interés artístico o importancia histórica".

47 Cfr. artículo $10 \mathrm{o}$.

48 Cfr. artículo 12.

49 Cfr. artículo 19.

50 Cfr. artículo 27.

51 Cfr. artículos $25 \mathrm{~g})$ y 31 . 
En fin, la ley republicana de confesiones religiosas recogía fielmente la prohibición constitucional de que las instituciones eclesiásticas fundaran o dirigieran - por sí o por personas interpuestas - centros dedicados a la enseñanza, salvo cuando se tratara de la difusión de sus doctrinas y de la formación de sus miembros. Y, aun en este caso, se matizaba que "la inspección del Estado garantizará que dentro de los mismos no se enseñen doctrinas atentatorias a la seguridad de la República" $^{, 52}$ (no es necesario insistir en el equívoco significado que podía darse a esas palabras en aquel contexto político).

Los aspectos de la Ley de 1933 que he señalado son suficientemente elocuentes respecto a la dirección de la política religiosa del gobierno de Azaña. Poco después, la coalición de las derechas republicanas encabezada por Gil Robles triunfaba en las elecciones de noviembre de 1933. Se iniciaba el llamado "bienio de derechas", que determinó una diferente actitud del gobierno hacia la Iglesia católica, y una más mitigada aplicación de la legislación vigente, pero en el que no se produjeron modificaciones legales de importancia. Ni siquiera se llegó —a pesar de que las circunstancias parecían propicias - a un convenio con la Santa Sede, bien fuera en forma de concordato o de un simple modus vivendi. ${ }^{53}$ Los intentos al respecto, alentados por el cardenal Vidal i Barraquer, tropezaron con diversos obstáculos. Entre ellos, la negativa del Pontífice a ningún acuerdo con el Estado de la Segunda República que no fuera precedido de una modificación de la "inicua" Constitución. ${ }^{54} \mathrm{Y}$ también lo poco operativo de un gobierno que, no obstante sus divergencias con el gabinete precedente, coincidía con él en aunar agitación y esterilidad.

Posteriormente, el triunfo del Frente Popular en las elecciones de febrero de 1936 marcaría el principio del fin de la Segunda República. La vida política y social española entró en una fase de creciente conflictividad, ${ }^{55}$ que desembocaría en el alzamiento militar del 18 de julio

52 Cfr. artículos 20 y 30.

53 En relación con esta materia, véase el excelente y documentado trabajo de Vázquez García-Peñuela, J. M., El intento concordatario de la Segunda República (1933-1935), Madrid, 1999, que, aparte de un riguroso análisis y un interesante relato de los hechos, saca a la luz importante documentación inédita, tras una cuidadosa y paciente exploración de los archivos de la Embajada de España ante la Santa Sede.

54 Véase Redondo, G., Historia de la Iglesia.., cit., pp. 229-243; Martí Gilabert, F., Política religiosa..., cit., pp. 188-200.

55 Incluido un nuevo despertar de hostilidades sociales contra la Iglesia católica: véase Cárcel Ortí, V., La persecución religiosa en España..., cit., pp. 185 y ss. 
y en la guerra civil. Pero esos sombríos acontecimientos quedan ya fuera del ámbito de mi intervención.

\section{CONSIDERACIONES FINALES}

Ya dije al inicio que mi objetivo consistía en esbozar, con la brevedad que permite esta exposición, una revisión crítica del modo en que la Segunda República resolvió la cuestión religiosa. Más bien habría que decir que dejó la cuestión religiosa sin resolver, y así permanecería hasta 1978.

$\mathrm{Y}$ es que, si hacemos un balance entre aciertos y desaciertos de la República en esta materia, el saldo resulta bastante negativo. Aunque sea un juicio severo, creo exacto afirmar que, contemplada en su totalidad y con la perspectiva que da el tiempo transcurrido, la política religiosa de la Segunda República fue notablemente desafortunada. Se actuó a menudo, en el mejor de los casos, con ligereza e imprevisión, cuando no con deliberada injusticia.

La principal razón, a mi juicio, fue la incapacidad para el diálogo político que demostraron las principales fuerzas sociales en aquellos momentos.

En los círculos católicos se podía observar un doble defecto. Por un lado, la falta de habilidad estratégica de los sectores políticos de inspiración católica para superar las propias divisiones y encontrar los cauces que hubieran permitido trazar una política religiosa más sensata y más realista. Por otro lado, la jerarquía eclesiástica se mostró excesivamente apegada a sus privilegios tradicionales, y demasiado celosa en mantener a ultranza la doctrina oficial de la Iglesia católica sobre la confesionalidad estatal; un régimen de separación entre Estado e Iglesia les parecía inadmisible. Además, en algunos ambientes católicos podía advertirse una cierta confusión entre la ortodoxia doctrinal y un rancio conservadurismo político y cultural.

Por su parte, en los sectores no católicos terminaron por imponerse las posiciones más extremas, pese a que las personas de mayor prestigio intelectual abogaban por la moderación, insistiendo en que la modernización del Estado no tenía por qué ir acompañada de una violencia antirreligiosa. Ese extremismo no nacía gratuitamente. Tenía su raíz en la intransigencia con que el establishment católico había impedido la libertad de expresión 
- y de expansión - de las ideas que consideraba heterodoxas, y en la escasa contribución que había prestado de hecho para superar las profundas desigualdades sociales existentes en la España de entonces: amplias áreas de las clases trabajadoras no miraban a la Iglesia ni con afecto ni con simpatía. ${ }^{56}$ Aun así, el excesivo rigorismo anticatólico no resultaba justificable ni, sobre todo, prudente. La política religiosa republicana no sólo fue represiva, sino también torpe. Para consolidar la República hubiera sido preferible atraer al clero - alto y bajo- a la causa republicana ${ }^{57}$ y haber procedido a la secularización del Estado con igual firmeza pero más paulatinamente.

La realidad, sin embargo, fue muy distinta. Sobre la conciliación se impuso el enfrentamiento, especialmente áspero entre católicos y socialistas. Mientras la Iglesia católica anatemizaba el socialismo, la izquierda con frecuencia idealizaba el comunismo al tiempo que demonizaba el sentimiento religioso, el cual era identificado subliminalmente con su versión católica. Ni unos ni otros supieron darse cuenta de lo que estaba en juego: no sólo la cuestión religiosa, sino la subsistencia de la Segunda República, y, más allá, la posibilidad misma de convivencia civilizada y pacífica entre opciones políticas e ideológicas diversas, y adversas. Por ello, más que la disensión religiosa en sí misma, lo que el triste devenir de la Segunda República puso verdaderamente al descubierto fue la carencia de tradición democrática en nuestro país.

$\mathrm{Si}$ atendemos a sus concretos resultados jurídicos en materia de libertad religiosa, la Constitución y la legislación republicana han pasado

56 En un escrito publicado en 1935, Salvador de Madariaga achacaba dos defectos principales a la Iglesia española: "su incultura y su sentido reaccionario en cuestiones económicas y sociales", Anarquía o jerarquía (ideario para la Constitución de la II República Española), Madrid, 1935, p. 218; citado por Cárcel Ortí, V., La Iglesia durante la II República..., cit., p. 342. El propio Cárcel Ortí, poco sospechoso de anticlericalismo, y una de las personas que más concienzudamente ha estudiado la historia de la Iglesia durante la Segunda República, comenta ese juicio de Madariaga con las siguientes palabras: "Se trata, evidentemente, de afirmaciones un tanto radicales hechas en el lejano 1935. Ciertamente deben ser matizadas, porque no siempre la Iglesia española fue así, pero para 1931 la imagen vale" (idem.).

57 Permítaseme citar de nuevo a Madariaga, comentando la extinción del presupuesto del clero que se decretaba en el artículo 26 de la Constitución: "La táctica en ese caso hubiera debido ser precisamente la contraria: aumentar el presupuesto del clero todo lo que fuera necesario para dignificar al cura de aldea a quien hubiera sido relativamente sencillo convertir a la República". La medida constitucional implicaba enviar al bajo clero, "su aliado potencial, al campo enemigo y condenándole a la inseguridad, a la pobreza y al resentimiento contra su agresor" (España. Ensayo de historia contemporánea, Madrid, 1978, p. 333). 
a la historia como un ejemplo de falta de realismo, pero también, y sobre todo, como un ejemplo de intolerancia religiosa, tanto más grave cuanto que contradecía otros derechos en principio garantizados por la propia Constitución. Dos fueron, en efecto, los objetivos principales que informaban la producción normativa de la Segunda República. El primero era poner la libertad religiosa - y en concreto la libertad de la Iglesiabajo un control gubernativo cuya discrecionalidad no estaba claramente limitada por la legislación, y podía por tanto degenerar en arbitrariedad. El segundo, imponer un modelo de enseñanza laica ideológicamente dirigida por el Estado.

Se puede intentar comprender esas opciones en el contexto social y cultural del momento, pero resulta difícil aceptarlas si nos situamos en las coordenadas de lo que hoy entendemos por respeto de los derechos fundamentales y de las libertades democráticas. De hecho, ni la legislación republicana en materia religiosa, ni los mismos dos objetivos mencionados, resistiría un análisis a la luz de los documentos internacionales sobre derechos humanos que surgen desde la Declaración Universal de Naciones Unidas de 1948. La jurisprudencia del Tribunal Europeo de Derechos Humanos es muy significativa al respecto. ${ }^{58}$

No obstante lo anterior, sería injusto emitir un juicio meramente negativo sobre la legislación republicana en materia religiosa. Antes dije que esa legislación perseguía dos objetivos principales, pero en realidad eran dos instrumentos para lograr una finalidad fundamental: reducir la influencia social y política de la Iglesia católica.

En las posiciones extremas - que acabarían por imponerse-, esa limitación de la influencia eclesiástica parecía concebirse como fin en sí misma, y debía efectuarse "a toda costa"; lo cual significó, a la hora de la verdad, que se efectuó a costa de imponer restricciones inaceptables a libertades personales y colectivas. Sin embargo, para personas más prudentes, representativas de lo que se dio en llamar "anticlericalismo

58 En efecto, desde 1976, el Tribunal Europeo de Derechos Humanos ha vetado que el Estado pueda realizar tarea alguna de adoctrinamiento religioso o ideológico en el marco de la enseñanza pública (dando por supuesto, además, que el Convenio Europeo de Derechos Humanos prohíbe el monopolio de la enseñanza por parte del Estado). Además, el Tribunal Europeo, en años recientes, ha estigmatizado, como contrarias a la libertad religiosa, políticas de control sobre las religiones que, como la griega, son considerablemente menos restrictivas que la política adoptada por la Segunda República española. Para ulteriores detalles sobre la noción internacional de libertad religiosa y sus consecuencias, me remito a Martínez-Torrón, J., La protección internacional de la libertad religiosa, en AA. VV., Tratado de derecho eclesiástico, Pamplona, 1994, pp. 141-239. 
intelectual", recortar el poder de la Iglesia no era sino el requisito imprescindible para modernizar el Estado y, a la postre, modernizar España. Y pensaban así porque de lo que se trataba era, en el fondo, de marcar los límites de la legítima autonomía respectiva del ámbito secular y del ámbito religioso: una idea que, paradójicamente, había sido aportada originariamente por el cristianismo a la cultura occidental, pero cuya trascendencia práctica había ido siendo paulatinamente echada en el olvido por la propia Iglesia católica, o sepultada frecuentemente bajo el peso de alianzas políticas. ${ }^{59}$

Naturalmente, la delimitación precisa de la frontera entre lo que corresponde a la sociedad civil y a la sociedad religiosa, y cuáles son sus consecuencias por lo que se refiere a la estructura política del Estado, era entonces, y sigue siendo hoy, materia abierta a la discusión. Pero la idea en sí misma era interesante y positiva, y constituía una novedad que rompía con el modo habitual de plantear el régimen de las relaciones entre Iglesia y Estado en España. De hecho, treinta años más tarde, en el Concilio Vaticano II, la Iglesia católica aceptaría con entusiasmo algunos de los razonamientos de ese "anticlericalismo intelectual" que tanto había escandalizado a los sectores católicos más tradicionalistas.

Lamentablemente, esos planteamientos de modernidad no encontrarían el adecuado clima de diálogo político durante la Segunda República, y quedarían ahogados en el desasosiego producido por los enfrentamientos entre el extremismo laicista y el catolicismo oficial. Aquél estaría dominado por un excesivo celo vindicatorio de agravios pasados; y éste, reacio a perder su hegemonía, mostraría una tenaz intransigencia hacia la secularización del Estado, sin comprender que la religiosidad de un pueblo hay que ganarla mediante la adhesión voluntaria y no mediante el apoyo del aparato coercitivo del Estado.

Se perdió así, en éste y en muchos otros aspectos, una oportunidad de progreso que sólo reaparecería muchos años después, cuando la Constitución de 1978, cerrando el largo y tenebroso paréntesis iniciado por la guerra civil, reanudó la tarea de transformar España en un Estado de libertades.

59 Véase al respecto las breves pero interesantes observaciones de Lombardía, P., "El derecho eclesiástico”, en AA. VV., Derecho eclesiástico del Estado español, 2a. ed., Pamplona, 1983, pp. 41 ss.; y Souto, J. A., Comunidad política y libertad de creencias, Madrid, 1999, pp. 22 y ss. 